Цимбалюк Ірина, кандидат економічних наук, доцент, Східносвропейський національний університет імені Лесі Українки, кафедра фінансів, банківської справи та страхування, м. Луцьк; ORCID ID 0000-0003-0506-2262 email: tsymbaliuk i@ukr.net

https://doi.org/10.29038/2411-4014-2019-04-157-165

\title{
ОЦІНКА ІНКЛЮЗИВНОГО РОЗВИТКУ РЕГІОНІВ УКРАЇНИ
}

Нові виклики сучасної парадигми суспільного зростання формують потребу оновленого бачення соціально-економічних змін на основі застосування інклюзивного підходу. У статті здійсненна оцінка рівня та динаміки інклюзивного розвитку регіонів України. Обгрунтована необхідність поглибленого дослідження розвитку регіону із врахуванням його інклюзивності, що розширює аналіз економічних зрушень, доповнюючи його показниками рівномірності розподілу отриманих благ та оцінкою можливостей включення усіх верств населення до процесів соціально-економічного зростання. Проведений аналіз інклюзивного розвитку регіонів за трьома складовими, що дозволяють в достатній мірі об'єктивно оцінити його рівень. Розрахунок інтегрального індексу, а також показників, що характеризують динаміку економічної, соціальної й інфраструктурної сфер дозволив встановити тенденції інклюзивного розвитку регіонів України та виявити наявність значної міжрегіональної асиметрії.

Ключові слова: оцінка розвитку, інклюзивний розвиток регіону, регіони України, соціальний розвиток, економічний розвиток, інфраструктурний розвиток.

Цимбалюк Ирина, кандидат экономических наук, доцент,

Восточноевропейский национальный университет имени Леси Украинки, доцент кафедры финансов, банковского дела и страхования, г. Луцк

\section{ОЦЕНКА ИНКЛЮЗИВНОГО РАЗВИТИЯ РЕГИОНОВ УКРАИНЫ}

Новые вызовы современной парадигмы общественного роста формируют потребность обновленного видения социально-экономических изменений на основе применения инклюзивного подхода. В статье осуществлена оценка уровня и динамики инклюзивного развития регионов Украины. Обоснована необходимость углубленного исследования развития региона с учетом его инклюзивности, что расширяет анализ экономических сдвигов, дополняя его показателями равномерности распределения полученных благ и оценкой возможностей включения всех слоев населения в процессы социально-экономического роста. Проведенный анализ инклюзивного развития регионов по трем составляющим, позволяющим в достаточной мере объективно оценить его уровень. Расчет интегрального индекса, а также показателей, характеризующих динамику экономической, социальной и инфраструктурной сфер позволил установить тенденции инклюзивного развития регионов Украины и выявить наличие значительного межрегиональной асимметрии.

Ключевые слова: оценка развития, инклюзивное развитие региона, регионы Украины, социальное развитие, экономическое развитие, инфраструктурное развитие.

Iryna Tsymbaliuk,

PhD in Economics, Associate Professor,

Lesya Ukrainka Eastern European National University, Associate Professor of the Department of Finance, Banking and Insurance, Lutsk

\section{EVALUATION OF INCLUSIVE DEVELOPMENT OF UKRAINIAN REGIONS}

New challenges of the contemporary social growth paradigm shape the need for a renewed vision for socioeconomic change based on an inclusive approach. The article assesses the level and dynamics of inclusive development of Ukrainian regions. Considering this, the analysis of the inclusive development of the regions becomes especially 
relevant for the needs of socio-economic growth in Ukraine. The purpose of the article is to evaluate the level and dynamics of inclusive development of Ukrainian regions. As a result of the research, the scientific and methodological approach to the analysis of the regional inclusive development trends in the conditions of financial decentralization was further developed. The article substantiates the need for in-depth study of the regional development, taking into account its inclusivity, which expands the analysis of economic shifts, supplementing it with indicators of the even distribution of the benefits received and assessing the possibilities of inclusion of all population segments in the processes of socio-economic growth. In accordance with the new requirements, an analysis of the inclusive regional development was conducted according to three components (economic, social and infrastructural), which allow a sufficient objective assessment of its level. The calculation of the integral index, as well as the indicators characterizing the dynamics of economic, social and infrastructural spheres, allowed to identify trends of inclusive development of the Ukrainian regions and to reveal the presence of significant interregional asymmetry. The results of the conducted research can be used in the activity of local and regional financial authorities in the system of executive power.

Key words: development assessment, inclusive development of the region, regions of Ukraine, social development, economic development, infrastructure development.

Постановка проблеми. Як показує практика, сучасний розвиток носить нерівномірний характер. Швидко зростаючі економіки низки країн все частіше зіштовхуються 3 поглибленням соціально-економічного нерівності та проблемою соціальної ізоляції в процесі розвитку [1, с. 56]. Такі тенденції обумовили поширення в науковій літературі досліджень інклюзивного розвитку, який не обмежується рамками традиційної моделі економічного зростання, акцентуючи увагу на значимості людського капіталу, максимальному залученні усіх верств населення до продуктивної праці, рівних можливостях та справедливому розподілі отриманих в результаті соціальноекономічного розвитку благ. Нові виклики сучасної парадигми суспільного зростання формують потребу оновленого бачення соціально-економічних змін на основі застосування інклюзивного підходу. Зважаючи на це проведення аналізу інклюзивного розвитку регіонів набуває особливої актуальності для потреб соціально-економічного зростання в Україні.

Аналіз останніх досліджень і публікацій. В останні роки у посилюється акцент на дотриманні соціально-інклюзивного підходу до забезпечення економічного зростання. Засади теорії інклюзивного розвитку заклали у своїх дослідженнях закордонні вчені: Anand R., Ianchovichina E., Gupta J., Lundstrom Gable S., Vegelin C. [2-4] та ін. Серед українських науковців дослідження інклюзивного розвитку та результати його оцінки представили у своїх працях Смельяненко Л., Петюх В., Федулова Л. [1; 5] та ін.

Водночас розпочата реформа децентралізації в Україні посилила інтерес наукової спільноти до обгрунтування об’єктивної методики аналізу розвитку регіонів. Сучасну парадигму регіонального розвитку розкривають у своїх працях Возняк Г., Павліха Н., Сторонянська І., Хомюк Н. [6-8] та ін. Разом тим, криза традиційних підходів до вимірювання економічного розвитку обумовлює потребу більш глибоко та диференційовано підходити до аналізу регіонального зростання через призму його інклюзивності.

Постановка завдання. Метою статті $є$ здійснення оцінки рівня та динаміки інклюзивного розвитку регіонів України. Для досягнення мети було поставлено наступні завдання: оцінити динаміку показників економічного, соціального та інфраструктурного зростання регіонів; встановити рівень міжрегіональної асиметрії інклюзивного розвитку.

Виклад основного матеріалу. Найбільш універсальним і часто вживаним індикатором оцінки регіонального розвитку $є$ валовий регіональний продукт (ВРП). В Україні протягом 2015 р. спостерігалося істотне падіння ВРП у зв'язку з воєнними діями на сході держави. Так, у 2015 р. найбільше скорочення індексів фізичного обсягу ВРП відбулось у Луганській (-52,3\%) та Донецькій $(-38,7 \%)$ областях (рис. 1$)$.

В цілому, найгірше відновлення ВРП відбувається у східних та центральних регіонах, у яких були міцні економічні зв’язки з Донецькою, Луганською областями та Російською Федерацією (Дніпропетровська, Запорізька, Сумська, Полтавська, Харківська області) та окремих західних областях (Тернопільська, Закарпатська). Натомість, кращі темпи відновлення ВРП демонструють західні, центральні та південні регіони. Що стосується останніх, то одним з головних факторів зростання їх економіки є переорієнтація туристичних потоків із тимчасово окупованої Автономної республіки Крим. 


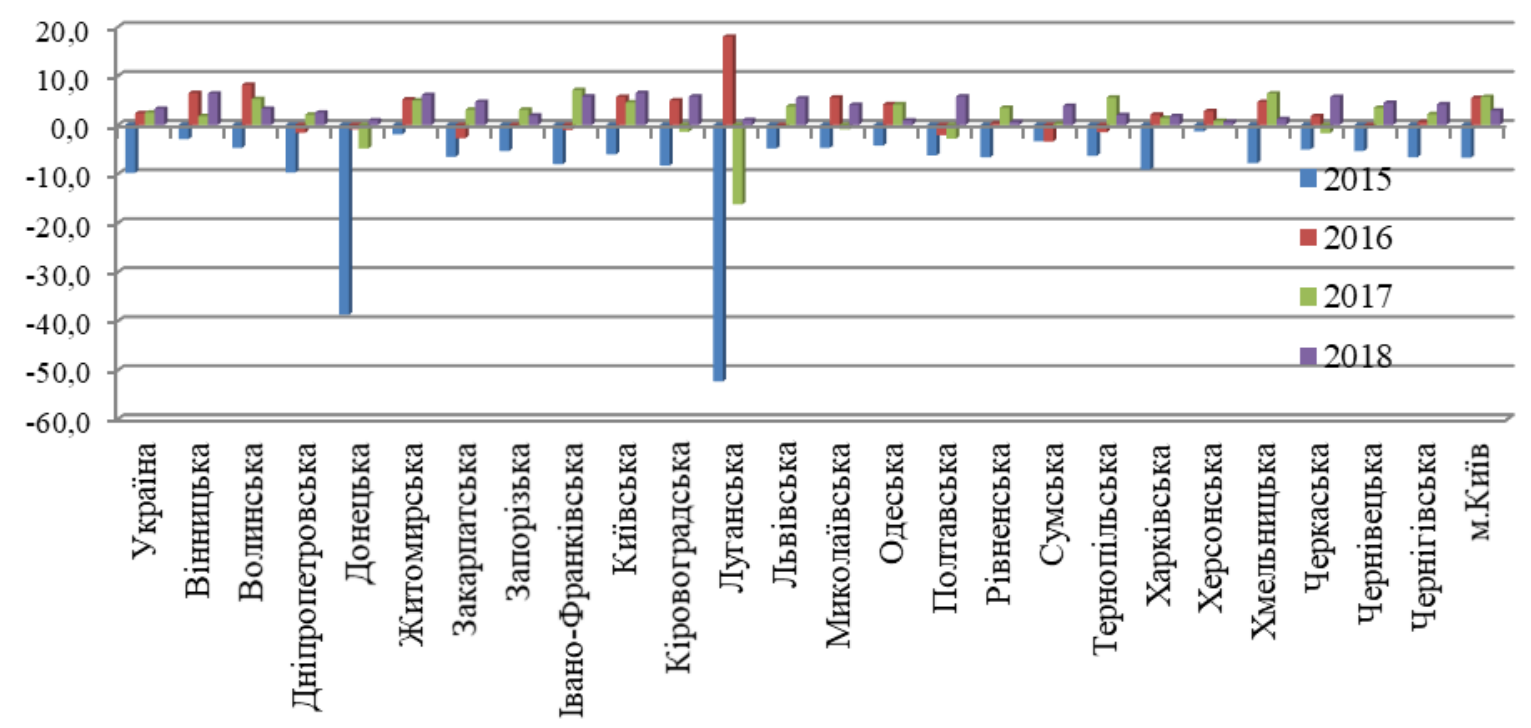

Рис. 1. Темпи приросту фізичного обсягу ВРП у 2015-2018 рр.

Джерело: складено за даними [9].

Найгірше відновлення ВРП відбувається у східних та центральних регіонах, у яких були міцні економічні зв'язки 3 Донецькою, Луганською областями та Російською Федерацією (Дніпропетровська, Запорізька, Сумська, Полтавська, Харківська області) та окремих західних областях (Тернопільська, Закарпатська). Натомість, кращі темпи відновлення ВРП демонструють західні, центральні та південні регіони. Що стосується останніх, то одним 3 головних факторів зростання їх економіки є переорієнтація туристичних потоків із тимчасово окупованої Автономної республіки Крим.

Показники експорту товарів свідчать що у 2015-2016 рр. вищі темпи зростання експорту товарів демонстрували західні і центральні регіони, що знову ж таки, пояснюється наявністю історичних торгівельних зв’язків східних регіонів України із Російською Федерацією. Однак у $2017-2018$ рр. ситуація дещо змінилась, так найвищі темпи нарощування обсягів експорту у 2018 р. показали Хмельницька. Чернівецька та Івано-Франківська області. Водночас в 10 регіонах, серед яких як східні, так і центральні та західні регіони (Донецька, Харківська, Рівненська, Київська, м. Київ, Волинська, Полтавська), зростання експорту відбувалось повільніше ніж в середньому по країні. У трьох регіонах (Херсонська, Одеська, Луганська) показники приросту були від’емними.

В останні роки змінилася географічна структура зовнішньої торгівлі регіонів. Відбувається переорієнтація експорту товарів і послуг з країн СНД на країни СС, Азії та Африки.

Індекс капітальних інвестицій мав тенденцію до зростання протягом 2015-2018 рр. практично у всіх регіонах України. Це свідчить про збільшення суб'єктами господарювання обсягів інвестування грошових коштів у матеріальні та нематеріальні активи. Обчислені показники вказують на тенденцію, що найбільші обсяги капітальних інвестицій були здійснені в економіку західних і південних областей.

Своєрідним мірилом ділової активності в регіоні є кількість активних підприємств. Історично найбільша чисельність активних підприємств присутня в м. Києві, Дніпропетровській, Одеській, Львівській, Харківській, Донецькій областях (рис. 2). Характерним є те, що протягом дослідженого періоду найбільше зниження числа активних підприємств відбувалося у Харківській, Донецькій та Луганській областях. 


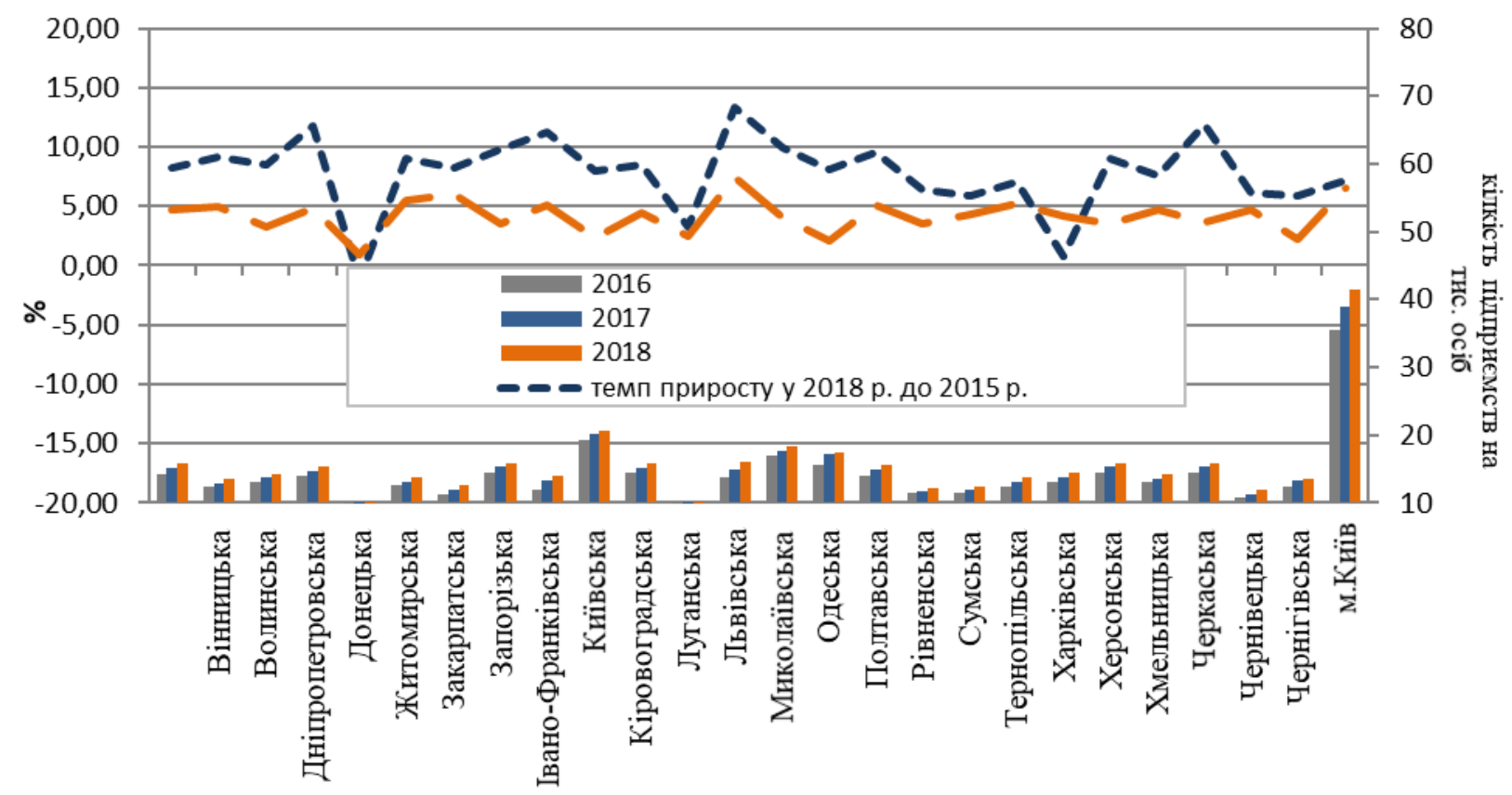

Рис. 2. Зміна кількості активних підприємств у розрахунку на тисячу осіб у регіонах України у 2015-2018 рр.

Джерело: складено автором за даними [9]

На основі індексу фізичного обсягу ВРП, темпу зростання експорту товарів, індексу капітальних інвестицій, темпу зростання кількості активних підприємств можна вивести індекс економічного розвитку регіонів (Іер) (рис. 3). Найдинамічніше протягом досліджуваного періоду розвивалася економіка м. Києва, а також Київської, Миколаївської та Дніпропетровської областей. У той же час, окрім Луганської та Донецької областей, ситуація в яких обумовлена складною політичною ситуацією, низький рівень економічної складової інклюзивного розвитку притаманний Рівненській, Чернівецькій, Тернопільській та Херсонській областям. Серед причин можна назвати сільськогосподарську орієнтацію господарства названих регіонів, відносно низьку економічну активність населення та міграцію робочої сили за кордон.

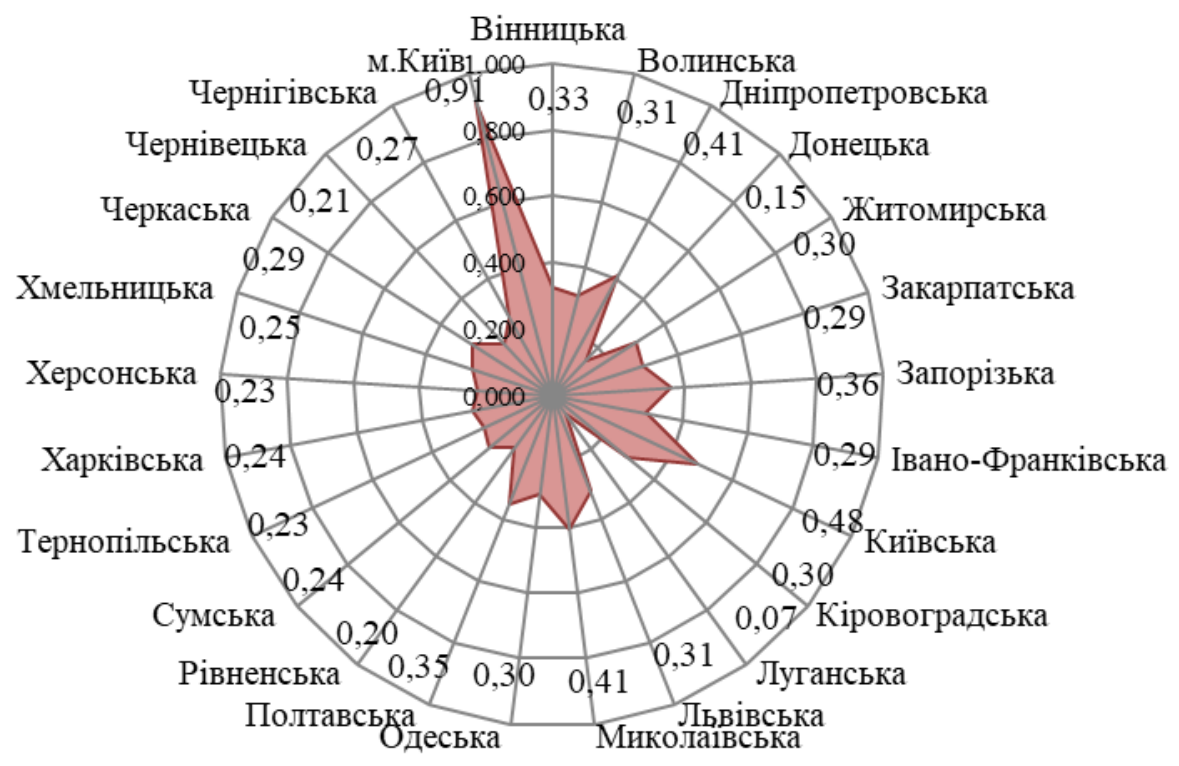

Рис. 3. Асиметрія економічного розвитку регіонів Украӥни за період 2015-2018 рр. Джерело: побудовано автором

Репрезентаційними показниками інклюзивного розвитку соціальної сфери є розмір доходів 
населення та їх диференціація як вертикальна (між різними верствами населення) так i горизонтальна (їх регіональна нерівномірність).

Для України характерною є суттєва різниця в оплаті праці у західних областях, промислово розвинутих східних регіонах і м. Києві. Розглядаючи динаміку середньомісячної заробітної плати можна відмітити, що найвищий іiі рівень спостерігався у м. Києві - від 5007 грн у 2013 р. до 13542 грн у 2018 р., що майже вдвічі перевищувало показники у Тернопільській області, де рівень оплати праці був найнижчим.

Водночас, як свідчать проаналізовані дані, цей розрив поступово скорочується. Якщо в 2015 p. співвідношення середньої заробітної плати м. Києва (найвища заробітна плата в Україні) та Тернопільської області (найнижча заробітна плата по країні) складало 2,25, то у 2017 р. - 2,01 (рис. 4.)

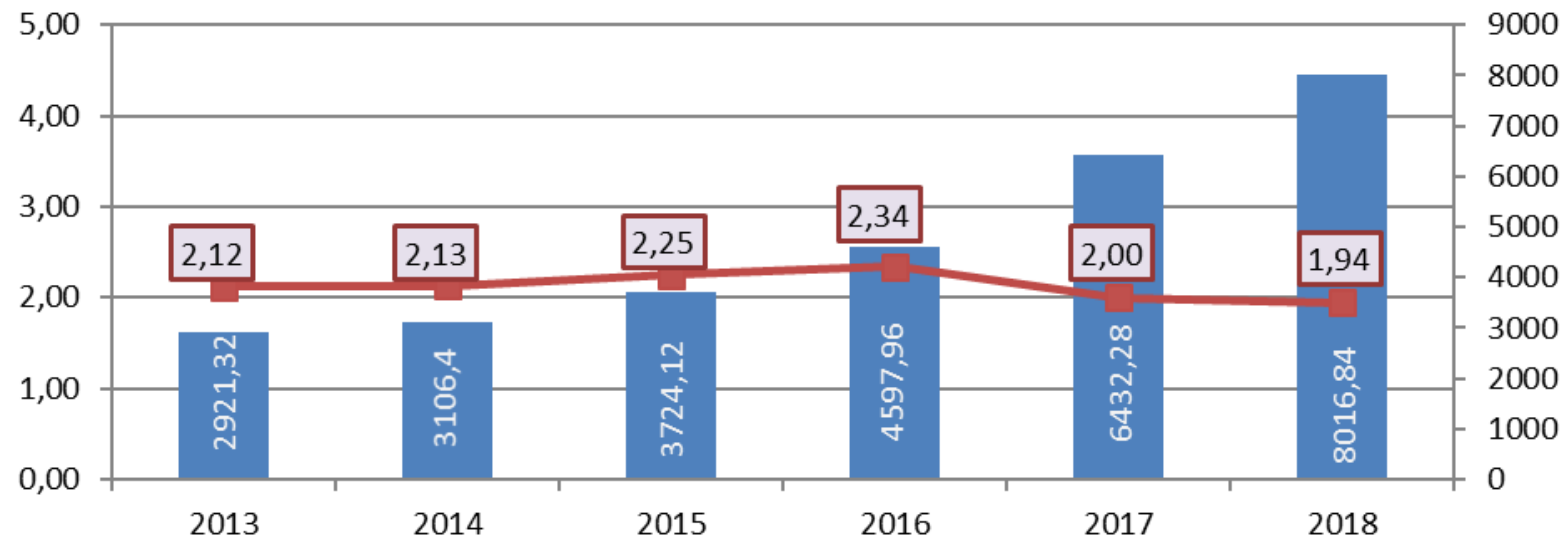

Середня заробітна плата по регоінах, грн.

- - Рівень диференціації заробітної плати, індекс

Рис. 4. Відношення середньомісячної заробітної плати протягом календарного року у Києві та Тернопільській області

Джерело: складено на основі [9]

Індекс реальної заробітної плати катастрофічно впав по всіх регіонах у 2015 р., склавши в середньому по Україні 79,8 \%, що пов'язано із воєнними діями на сході України. У 2016 р. реальна заробітна плата в Україні стабільно зростала, причому найвищі показники були зафіксовані у західних областях. У 2018 р. заробітна плата хоч і продовжувала зростати, однак меншими темпами, про що свідчить динаміка індексу реальної заробітної плати.

Рівень доходів у м. Києва, де розмір їх розмір був найбільшим, перевищував доходи населення в інших регіонах в середньому у два рази, однак позитивною $є$ динаміка скорочення такої диференціації починаючи 32016 року. Найнижчий рівень доходів спостерігається у Луганській, Донецькій та Закарпатській областях, населення яких в 3,5-7 раз бідніші ніж жителі м. Києва.

Водночас за результатами оцінки домогосподарств найбіднішими вважають себе жителі ІваноФранківської та Черкаської областей, де 99,3 \% та 99,1 \% відповідно віднесли себе до категорії незаможних (рис. 5).

Інклюзивність розвитку відображає рівень залучення населення регіону до продуктивної діяльності, показником чого є рівень зайнятості населення. Протягом 2015-2017 рр. кількість зайнятого населення зменшувалася по всій Україні, що стало наслідком припинення діяльності підприємств на непідконтрольних територіях, закриття або зменшення обсягів діяльності суб' єктами господарювання у зв'язку з військовими діями, масового виїзду населення України на постійні і тимчасові роботи за кордон через неприйнятно низький рівень заробітної плати в Україні. Однак у 2018 р., як свідчать дані, негативну тенденцію вдалось перервати і по країні в цілому спостерігалося незначне підвищення кількості зайнятих осіб, що стало однією із причин зменшення темпів росту вакансій у цьому ж році. 


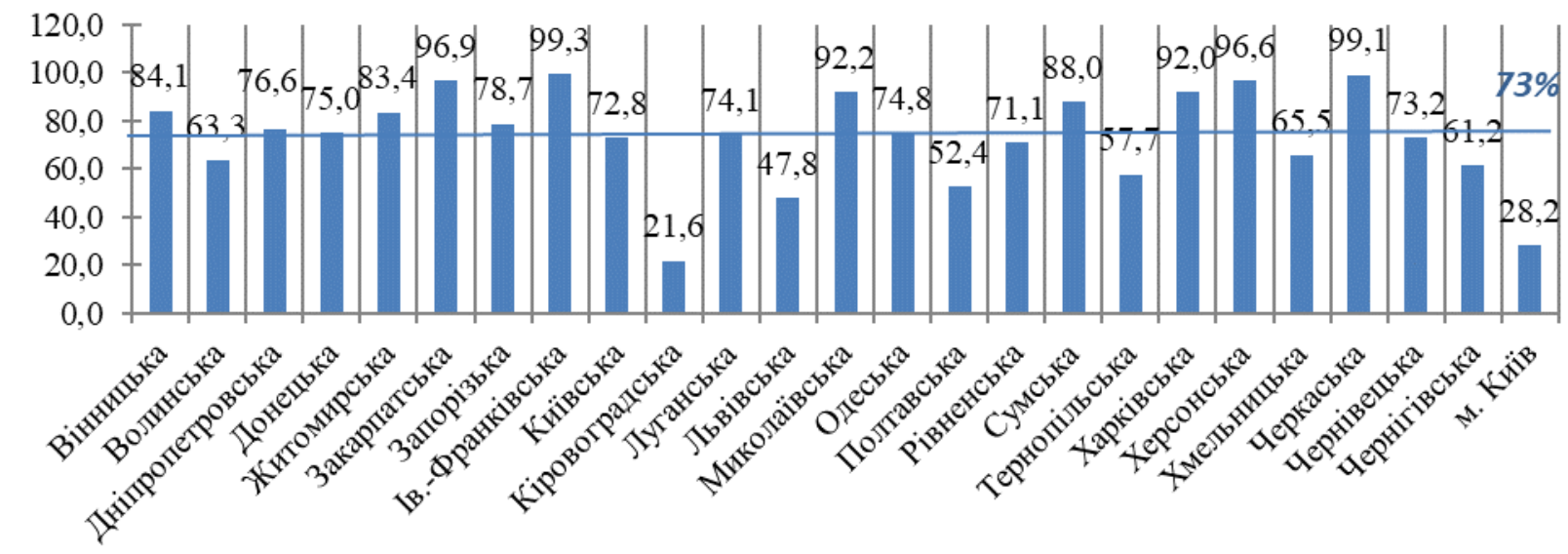

Рис. 5. Розподіл домогосподарств, які за оцінкою матеріального добробуту відносять себе до бідних, станом на 2019 р., \%

Джерело: складено автором за даними [9]

Негативним явищем є стабільне зменшення чисельності населення в Україні, що відбувається як 3 природних, так і з міграційних причин. Приріст населення відбувався лише у м. Києві та Київській області, найбільше скорочення було характерне для східних областей України.

Проаналізовані показники реальної заробітної плати та її регіональної диференціації, динаміки рівня зайнятості та кількості вакансій, темпів росту чисельності населення дозволяють об'єктивно оцінити можливості доступу населення до продуктивної діяльності та процесів соціальноекономічного зростання країни і іiі регіонів. У своїй сукупності вони відображають інклюзивність розвитку соціальної сфери (рис. 6).

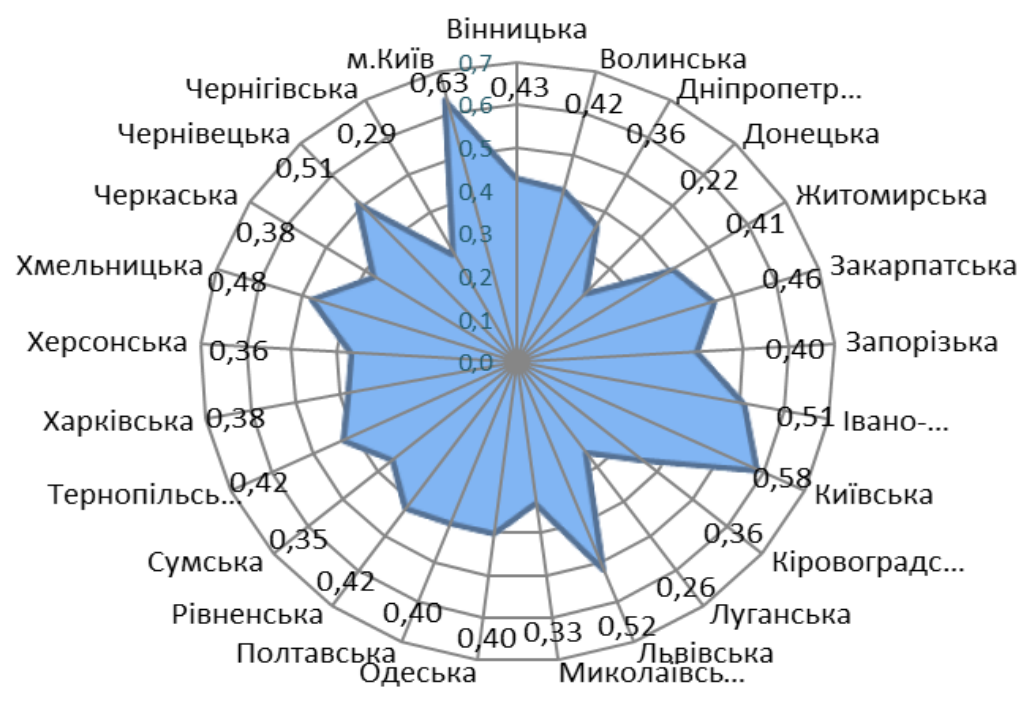

Рис. 6. Асиметрія соціального розвитку регіонів України за період 2015-2018 рр.

Джерело: побудовано автором

Як помітно з рисунку 6 асиметрія соціального розвитку регіонів України також наявна, однак іiі рівень дещо нижчий в порівнянні із економічним розвитком. Лідерами лишаються м. Київ, Київська та Львівська області, де середній інтегральний показник соціального розвитку за період 2015-2018 рр. ставив 0,63, 0,58 та 052 відповідно.

Стан інфраструктури є важливим чинником та одночасно результатом ефективного управління розвитком регіону, його інклюзивної спрямованості. Складові інфраструктурного комплексу створюють умови для повного використання трудового потенціалу та соціальної залученості 3 метою подолання бідності населення, підвищення доступності результатів соціально-економічного зростання для більшої частини населення і є головними елементами, що спроможні вивести нашу державу на новий рівень розвитку забезпечивши його інклюзивність. 
Серед показників розвитку інфраструктури, варто відзначити темпи зростання введеного в експлуатацію житла, аналіз яких свідчить про відсутність чіткої визначено тенденції. Із початком фінансової децентралізації у 2015 р. відбувалося зростання ринку житлової нерухомості, однак уже починаючи 3 наступного 2016 p. ситуація змінилась на протилежну. Однією із причин зміни інтенсивності житлового будівництва можна назвати довгий цикл між початком будівництва житла i його готовності до використання. Протягом дослідженого періоду лише у трьох регіонах спостерігалося стабільне зростання кількості введеного в експлуатацію житла: Київська, Харківська та Волинська області.

Індекс будівельної продукції практично у всіх регіонах у 2015 р. становив менше одиниці, а у 2016-2017 рр. демонстрував зростання. Це свідчить про підвищення обсягів будівництва будівель, споруд, інженерних споруд після кризового 2015 року. Чітких територіальних відмінностей виконання будівельно-монтажних робіт у розрізі регіонів немає, окрім найнижчих показників у Донецькій і Луганській областях.

Оцінюючи інклюзивний розвиток через доступність до послуг з охорони здоров'я, відмітимо, що кількість закладів лікарняних та лікарських амбулаторно-поліклінічних закладів у регіонах України поступово зростала, при чому найбільший ріст спостерігався у м. Києві. Вказані зміни відбувалися внаслідок поширення приватних лікарських закладів, роль яких, на нашу думку, зростатиме і надалі у зв'язку з проведенням реформи охорони здоров'я.

Кількість місць у дошкільних навчальних закладах збільшувалася майже по всіх регіонах України. Найшвидші темпи приросту цього показника були притаманні західним регіонам, а також Києву і Київській області. Утім, незважаючи на фактичне збільшення, проблема забезпечення дітей дошкільною освітою лишається актуальною в більшості обласних центрів.

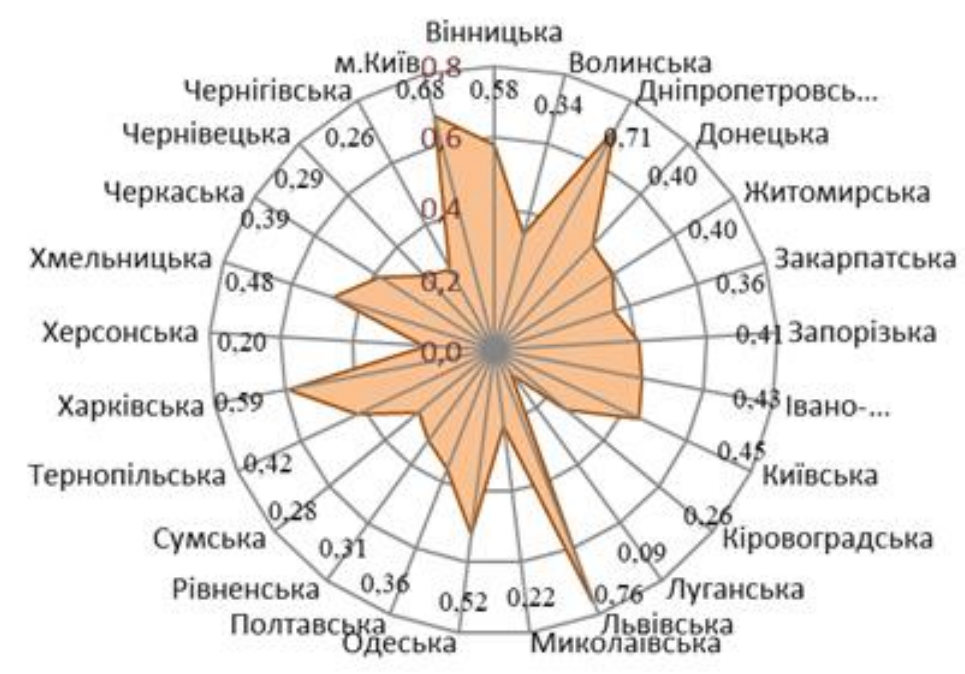

Рис. 7. Асиметрія інфраструктурного розвитку регіонів України у середньому за 2015-2018 рр. Джерело: побудовано автором

На основі темпу зростання обсягу введеного в експлуатацію житла, індексу будівельної продукції, темпу зростання кількості закладів охорони здоров’я, темпів зростання чисельності місць в закладах дошкільної освіти сформований індекс інфраструктурного розвитку регіону (Icp), який відображає можливість включення усіх верств населення до продуктивної діяльності та створення умов для зростання (рис. 7).

У підсумку за період 2015-2018 рр. найкращі показники інфраструктурного розвитку були у Львівській, Дніпропетровській областях та м. Києві, найгірші - у Луганській, Миколаївській та Херсонській областях. Починаючи 32017 р. 3 метою розвитку регіональної інфраструктури вирівнювання міжрегіональної асиметрії був удосконалений механізм фінансування проектів регіонального розвитку із державного бюджету. Так, при складанні Державного бюджету України сума коштів у фонд регіонального розвитку передбачається в розмірі не менше $1 \%$ від доходу загального фонду державного бюджету. 
Для узагальненої оцінки розрахований інтегральний індекс, що враховує економічну, соціальну та інфраструктурну складові, відповідно до якого проведене групування та рейтингове оцінювання регіонів України за рівнем інклюзивного розвитку табл. 1.

Індекс інклюзивного розвитку регіонів

\begin{tabular}{|c|c|c|c|c|c|c|}
\hline Область & 2015 & 2016 & 2017 & 2018 & Середнє значення & Бали \\
\hline м. Київ & 0,77 & 0,718 & 0,715 & 0,609 & 0,703 & 8 \\
\hline Київська & 0,560 & 0,484 & 0,617 & 0,548 & 0,552 & 5 \\
\hline Львівська & 0,525 & 0,406 & 0,554 & 0,411 & 0,474 & \multirow{2}{*}{4} \\
\hline Івано-Франківська & 0,520 & 0,363 & 0,552 & 0,417 & 0,463 & \\
\hline Дніпропетровська & 0,490 & 0,326 & 0,492 & 0,473 & 0,446 & \multirow{14}{*}{3} \\
\hline Вінницька & 0,487 & 0,359 & 0,475 & 0,459 & 0,445 & \\
\hline Закарпатська & 0,461 & 0,363 & 0,524 & 0,423 & 0,443 & \\
\hline Запорізька & 0,479 & 0,397 & 0,469 & 0,420 & 0,441 & \\
\hline Полтавська & 0,471 & 0,328 & 0,479 & 0,482 & 0,440 & \\
\hline Хмельницька & 0,488 & 0,386 & 0,551 & 0,337 & 0,440 & \\
\hline Чернівецька & 0,481 & 0,396 & 0,523 & 0,361 & 0,440 & \\
\hline Волинська & 0,522 & 0,376 & 0,451 & 0,386 & 0,434 & \\
\hline Миколаївська & 0,511 & 0,392 & 0,449 & 0,368 & 0,430 & \\
\hline Житомирська & 0,433 & 0,372 & 0,492 & 0,419 & 0,429 & \\
\hline Одеська & 0,497 & 0,386 & 0,462 & 0,354 & 0,425 & \\
\hline Тернопільська & 0,436 & 0,346 & 0,447 & 0,415 & 0,411 & \\
\hline Черкаська & 0,479 & 0,331 & 0,417 & 0,418 & 0,411 & \\
\hline Кіровоградська & 0,449 & 0,351 & 0,463 & 0,364 & 0,407 & \\
\hline Рівненська & 0,466 & 0,327 & 0,425 & 0,380 & 0,400 & \multirow{5}{*}{2} \\
\hline Харківська & 0,460 & 0,360 & 0,469 & 0,307 & 0,399 & \\
\hline Сумська & 0,443 & 0,330 & 0,465 & 0,322 & 0,390 & \\
\hline Херсонська & 0,451 & 0,358 & 0,457 & 0,289 & 0,389 & \\
\hline Чернігівська & 0,407 & 0,299 & 0,455 & 0,330 & 0,373 & \\
\hline Донецька & 0,324 & 0,283 & 0,357 & 0,270 & 0,308 & \multirow[b]{2}{*}{1} \\
\hline Луганська & 0,195 & 0,449 & 0,263 & 0,287 & 0,299 & \\
\hline
\end{tabular}

Джерело: розраховано автором

Критично оцінюючи динаміку інклюзивного розвитку регіонів, можна відмітити низьку динаміку позитивних зрушень та наявність значної міжрегіональної асиметрії. Вирішення окреслених проблем вбачається у адаптації до нових умов реформування фінансової системи, що відбувається в країні, та ефективному використанні можливостей від децентралізації.

Висновки і перспективи подальших досліджень. На основі проведеного дослідження була обгрунтована необхідність поглибленого дослідження розвитку регіону із врахуванням його інклюзивності, що розширює аналіз економічних зрушень доповнюючи його показниками рівномірності розподілу отриманих благ та оцінкою можливостей включення усіх верств населення до процесів соціально-економічного зростання. У відповідності до нових вимог був проведений аналіз інклюзивного розвитку регіонів за трьома складовими (економічною соціальною та інфраструктурною), що дозволяють в достатній мірі об'єктивно оцінити його рівень.

Розрахунок інтегрального індексу, а також показників, що характеризують динаміку економічної, соціальної й інфраструктурної сфер дозволив встановити тенденції інклюзивного розвитку регіонів України та виявити наявність значної міжрегіональної асиметрії. Як свідчать результати проведеного аналізу, упродовж досліджуваного періоду динамічніше розвивалися столичні (м. Київ та Київська область) та західні регіони (Львівська та Івано-Франківська області), що пояснюється, насамперед, меншим впливом військових дій та вищою адаптивністю цих областей до нових зовнішньоекономічних та соціальних умов.

Водночас ключовою ланкою, здатною забезпечити прискорений інклюзивний розвиток регіону в умовах фінансової децентралізації, є базовий рівень (міста обласного значення, ОТГ), на який 
передаються повноваження та відповідальність за надання якісних публічних послуг населенню, підвищення рівня його добробуту. Тому в перспективі дослідження інклюзивного розвитку регіонів в умовах фінансової децентралізації варто доповнити аналізом показників ефективності функціонування територіальних громад та їх можливості впливати на процеси залучення населення до продуктивної праці та соціально-економічного зростання.

\section{Джерела та література}

1. Федулова Л. І. Інклюзивні інновації в системі соціально-економічного розвитку. Економіка: реалії часу. 2016. № 3(25). C. 56-65.

2. Anand R. et al. Inclusive Growth: Measurement and Determinants. IMF Working Paper, 2013. P. 3. URL: http://www.imf.org/external/pubs/ft/wp/2013/wp13135.pdf. (дата звернення: 01.10.2019).

3. Ianchovichina E. and Lundstrom Gable S. eds. R. Arezki, C. Pattillo, M. Quintyn, and M. Zhu, "What Is Inclusive Growth?" In Commodity Prices and Inclusive Growth in LowUIncome Countries. Washington, DC:

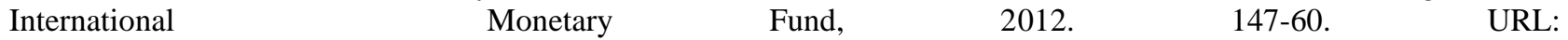
http://siteresources.worldbank.org/EXTPREMNET/Resources/WhatIsIG.pdf?resourceurlname=WhatIsIG.pdf $\quad$ (дата звернення: 18.10.2019).

4. Gupta J., Vegelin C. Sustainable development goals and inclusive development. International Environmental Agreements: Politics, Law and Economics, 2016. Vol. 16(3). P 33-448. URL: https://link.springer.com/article/10.1007/s10784-016-9323-z (дата звернення: 25.10.2019).

5. Смельяненко Л. М., Петюх В. М., Дзензелюк К. В. Інтегральна оцінка інклюзивного розвитку в Україні на національному та місцевому рівнях. Економіка та держава. 2019. № 6. С. 4-10.

6. Возняк Г. В. Регіональний розвиток: сутність і методологічна основа. Регіональна економіка. 2015. № 3. C. $34-43$.

7. Хомюк Н. Л., Павліха Н. В. Методичні підходи до аналізу розвитку сільських територій в умовах децентралізації. Регіональна економіка. 2019. № 1. С. 47-55.

8. Сторонянська I. З., Беновська Л. Я. Особливості фінансового вирівнювання розвитку територій в умовах бюджетної децентралізації. Фінанси України. 2018. №6. С. 58-74.

9. Державна служба статистики України. Статистична інформація. Офіщійний сайт. 2019. URL: www.ukrstat.gov.ua (дата звернення: 25.10.2019).

\section{References}

1. Fedulova, L. I. (2016). "Inclusive innovations in socio-economic development". Ekonomika: realii chasu. No. 3(25). Pp. 56-65.

2. Anand, R. et al. (2013). "Inclusive Growth: Measurement and Determinants". IMF Working Paper. P. 3. Available at: http://www.imf.org/external/pubs/ft/wp/2013/wp13135.pdf (in English) (accessed 01 October 2019).

3. Ianchovichina, E., and Lundstrom, Gable S. in ed. by Arezki, R., Pattillo, C., Quintyn, M., and Zhu M., (2012)."What is Inclusive Growth?" Commodity Prices and Inclusive Growth in Low-Income Countries. International Monetary Fund.

Available

at: http://siteresources.worldbank.org/EXTPREMNET/Resources/WhatIsIG.pdf?resourceurlname=WhatIsIG.pdf ～(in English) (accessed 18 October 2019).

4. Gupta, J., Vegelin, C. (2016). "Sustainable development goals and inclusive development". International Environmental Agreements: Politics, Law and Economics. No 16(3). P 33-448. Available at: https://link.springer.com/article/10.1007/s10784-016-9323-z (in English) (accessed 25 October 2019).

5. Yemelianenko, L. M., Petiukh, V. M., and Dzenzeliuk, K. V. (2019). "Integrated assessment of inclusive development in Ukraine at national and local levels". Ekonomika ta derzhava. No. 6. Pp. 4-10.

6. Vozniak, H. V. (2015). "Rehionalnyi rozvytok: sutnist i metodolohichna osnova" [Regional development: essence and methodological basis]. Rehionalna ekonomika. no. 3. P. 34-43.

7. Khomiuk, N. L., and Pavlikha, N. V. (2019). "Methodological approaches to analysis of rural territories' development in terms of decentralization". Rehionalna ekonomika. No. 1. Pp. 47-55.

8. Storonianska, I. Z., and Benovska, L. Ya. (2018). "Features of financial equalization of territories development in the conditions of budgetary decentralization". Finansy Ukrainy. No. 6. Pp. 58-74.

9. State Statistics Service of Ukraine (2019). Statistical information. Official site. Available at: www.ukrstat.gov.ua (accessed 25 October 2019). 